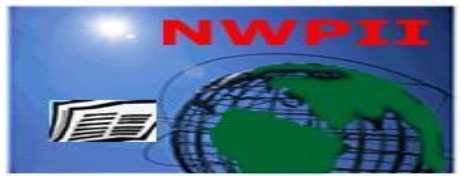

\title{
Prevalence of Herpes Simplex Virus Type-2 Infection among Pregnant Women in Port Harcourt Rivers State, Nigeria.
}

\author{
Onoriode Okpako Diamreyan ${ }^{1}$, Smart Enoch Amala², Easter Godwin Nwokah²
}

\author{
${ }^{1}$ Department of Medical Microbiology, University of Port Harcourt, Rivers State, Nigeria \\ ${ }^{2}$ Department of Medical Laboratory Science, Rivers State University, Port Harcourt, Rivers State, Nigeria \\ *Corresponding Author \\ Onoriode Okpako Diamreyan \\ Department of Medical Microbiology, University of Port Harcourt \\ Rivers State \\ Nigeria \\ Tel:+23408032568294 \\ Emai:diamreyanonoriode@gmail.com
}

Received:06 December 2020; $\mid$ Revised:15 April 2021; | Accepted:02 May 2021

\begin{abstract}
Herpes simplex virus type 2 (HSV-2) is a common human pathogen that can cause primary and recurrent infection of the mucous membrane. Genital infection with HSV-2 facilitates the acquisition of HIV. Infection with HSV-2 is a public health problem as a leading cause of genital ulcerative disease. This study is aimed at evaluating the prevalence of HSV-2. This is a cross-sectional study conducted at the antenatal unit of the University of Port Harcourt Teaching Hospital (UPTH), Rivers state. A total of 168 consenting pregnant women were used for the research. The study involved collecting socio-demographic data and laboratory determination of HSV-2 immunoglobulin (lgG). Data analysis was done using SPSS version 21. Chi square analysis was used to determine the correlation of the infection with socio-demographic factors. The seroprevalence for HSV-2 $\lg$ G specific antibody was $58.9 \%\left({ }^{99} / 168\right)$. Statistical association can be found between the prevalence of HSV-2 lgG antibodies and the age, marital status, type of family, religion, history of abortion, history of sexually transmitted diseases $(\mathrm{p}<0.05)$ while the level of education, occupation, parity and gestation period were not statistically significant with HSV-2 IgG seroposivity $(\mathrm{p}>0.05)$. The prevalence of HSV-2 was high among women of childbearing age in Port Harcourt, Rivers State, Nigeria. Effort should be made to increase the awareness of HSV-2 infection among women of childbearing age. HSV-2 should be included as a routine test.
\end{abstract}

Keywords: Prevalence, HSV-2, Pregnant, Women

\section{Introduction}

Herpes simplex virus type-2 (HSV-2) is a sexually transmitted infection disease and also a major cause of genital herpes. It may be infectious either during symptomatic or asymptomatic periods. The infection is one of the factors for acquisition and transmissions of human immunodeficiency virus (HIV) ${ }^{[2]}$ In 2012, it was reported that close to 417 people (about 11.3 in the age group between 15 
- 49 years) have been shown to be living with HSV2 Worldwide of which 267 million where women with Africa having the highest burden. The WHO in 2016 estimated that about 36.7 million people are globally living with HIV/AIDS, With sub-Saharan Africa having two-thirds of the population ${ }^{[4]} \mathrm{HSV}$ 2 prevalence rate is higher among women when compared with men and among pregnant women than non-pregnant women. HSV-2 and HIV coinfection among pregnant women may increase the danger of maternal-to-fetal transmission by as much as $25 \%{ }^{[4]}$. Since the late 1970s HSV-2 seroprevalence has increase to $30-36 \%$ by age 50. This prevalence is highest among Homosexuals $33 \%$ and prostitutes $75 \%{ }^{[7]}$. The prevalence of HSV-2 is high among women in Africa than men in the ratio of $78 \%$ in $15 \%$ respectively. Presently, no vaccine has been developed to prevent, HSV-2 acquisition or reactivation ${ }^{[1]}$. However, the antivirals acyclovir, valaciclovir and famciclovir have been observes to be safe and effective in reducing HSV-2 shedding rate and duration of genital ulcer disease (Abu Raddad et al., 2002).

HSV-2 infection is common among women of reproductive age and it can be contracted and transmitted to the foetus during pregnancy and the newborn. Herpes simplex virus is a major cause of neonatal infection which can lead to death or longterm disabilities. The greatest risk of transmission of the infection to the foetus and the newborn occur during initial maternal infection contracted at the late stage of pregnancy ${ }^{[3]}$. However, HSV contracted in the course of pregnancy has been shown to be connected with spontaneous abortion which occur highest in first trimesters ${ }^{[18]}$.

Herpes simplex 1 and 2 can infect both humans and other animals such as cats, mice and dogs but only humans show symptoms of disease ${ }^{[11]}$. The transmission of herpes simplex virus (HSV) infection is dependent upon intimate, personal contact of susceptible seronegative individual with someone excreting HSV ${ }^{[26]}$. Virus must come in contact with mucosal surfaces or abraded skin for infection to be initiated. After inoculation onto the skin or mucous membrane, there is an incubation period of about four to six days before herpes simplex virus begins to replicate in epithelial cells [8].
When Primary HSV infection occurs during late pregnancy, there is no adequate time to develop antibodies that is pertinent to suppress viral replication before labour ${ }^{[21]}$. HSV -2 can result to 2-3 fold increase in the risk of developing HIV infection ${ }^{[15]} \mathrm{HSV}$ infection in women are primarily asymptomatic but can have the following sign; painful erythematous papules, followed by vesicles and finally erosion on the vulva, labia major and minor, vagina and cervix, lasting for mainly 8-10 days. However, recurrent herpes can be asymptomatic or symptomatic ${ }^{[5]}$.

Latency is established when herpes simplex virus reaches the dorsal root ganglia after retrograde transmission via sensory nerve pathways. In its latent form, viral DNA is maintained in a nonreplicative state and remains in the nucleus as an episome for the entire life of the individual ${ }^{[19]}$. This study is to determine the prevalence of HSV-2 $\operatorname{lgG}$ infection among pregnant in Port Harcourt.

\section{Materials and Method}

\subsection{Research (Study) Design}

This was a cross-sectional study conducted at the antenatal unit of the University of Port Harcourt Teaching Hospital (UPTH) Rivers State, Nigeria. Questionnaires were distributed to pregnant women and the results from the feedback were used to obtain socio-demographic characteristics.

\subsection{Study Area and Population}

The respondents were pregnant women receiving antenatal care at University of Port Harcourt Teaching Hospital (UPTH) which is located on the East West Road, Port Harcourt, Nigeria. It is the major tertiary-health care teaching and research institution in Rivers State. It was founded in 1980 and has a bed capacity of 500 . UPTH is located on coordinates $4^{\circ} 5358 \mathrm{~N}$, $6^{\circ} 5543 \mathrm{E} / 4.89944^{\circ} \mathrm{N}, 6.92861^{\circ} \mathrm{E}$.

A total of 168 pregnant women meet the inclusion criteria which was pregnancy, while nonpregnant women were excluded from this study.

\subsection{Specimen Collection and Handling}

About $5 \mathrm{mls}$ of venous blood was collected aseptically by venipuncture from each respondents into plain bottles and allowed to clot. The sera were 
separated by centrifugation at $3000 \mathrm{rpm}$ at room temperature for 10 minutes and stored in aliquot in the freezer at $20^{\circ} \mathrm{C}$. Samples were clearly represented with codes for proper identification of specimens and also to avoid misinterpretation of results.

\subsection{Ethical Approval}

An Ethical Approval was obtained from the Institutional Review Board of the University of Port Harcourt Teaching Hospital, Port Harcourt, Rivers State.

\subsection{Data Analysis}

Data were analyzed using statistical package for social sciences (SPSS) version 21. Chi square analysis was used to assess correlation of the infection with socio-demographic factors.

\section{Results}

\section{Characteristic of the Respondents and Prevalence of HSV}

The final total number of samples used in this study was 168, after haemolysed samples containing residues of fibrin and heavy particle were discarded.

The mean age of the one hundred and sixty eight respondents finally used for the study was 32.17 (SD 5.69) years and the age range is 20-49 years. Majority of the women were within the age group 30-39 (61.9\%). Almost all the women 166 $(98.8 \%)$ were married. Majority of the respondents had some level of education with more than half of the $149(88.7 \%)$ having tertiary-level education. However, $59(35.1 \%)$ of the respondents were civil servants while $27(161.1 \%)$ were unemployed. A larger number of the respondents $136(81.0 \%)$ were in a monogamous relationship. Religiously 154 (91.7\%) were Christian by religion while 97 $(57.7 \%)$ have no history of abortion. However 74 $(44.1 \%)$ have 1-2 children. Majority of the respondents were in their 2nd and 3rd trimesters with seropositivity of $74(44.1 \%)$ and 75 (44.6\%) respectively, and $20(11.9 \%)$ having history of sexually transmitted diseases (STD)
Out of the 168 respondents investigated for HSV-2, 99(58.9\%) were found to be seropositive for HVS-2 IgG. Table 1 represents the sociodemographic factor associated with HSV-2 $\operatorname{lgG}$. Age, marital status, type of family, religion, history of abortion and history of sexually transmitted diseases $(p<0.05)$ were observed to be significantly associated with the respondents' HSV-IgG infection while no significant correlation was found among factors such as educational level, occupation, parity and gestation period $(\mathrm{p}<0.05)$. Table 1 Demographic factors associated HSV-2 IgG.

\section{Discussion}

Herpes simplex virus (HSV) causes a common sexually transmitted infection (STI) and the prevalence of this infection has increased significantly over the last two decades in many developed and developing countries.

A seroprevalence of $\mathrm{HSV}-2$ IgG infection among pregnant women in this study was $58.9 \%$. When compared with similar studies in other parts of Nigeria, it was lower in Enugu, it was $78 \%$ as observed by Ojinmah et al., 2012; 71.7\% among Katsina populace as observed by Hayatuden et al., 2016 and 87\% was recorded by Agabi et al, 2010) among patients attending STI clinic in Jos; was $82.2 \%$ was documented among women of reproductive age in Zaria, Kaduna State by Ameh et al., 2016. It is however hi her than $44.3 \%$ as reported in Benin, Nigeria by Kalu et al., 2014. When compared with findings from other African countries, it is similar to the prevalence rate of $58 \%$ HSV-2 IgG reported among the populace in Kampala, Uganda by Nakku-Joloba et al., 2014.

Ghazi et al., 2002 observed a high seropositivity of $90.9 \%$ and $27.1 \%$ for HSV-I and HSV-2 $\operatorname{lgG}$ in 926 pregnant women among Saudi women respectively. Sauerbrei et al., 2011 had a prevalence of $82.0 \%$ and $18 \%$ for HSV-1 and HSV$2 \mathrm{lgG}$ among pregnant women of Thuringia, Germany. Xu et al., 2006 in the United State, reported a $72 \%$ overall seropositivity of HSV among pregnant women. 
Table 1: Demographic factors associated with HSV -2 IgG

\begin{tabular}{|c|c|c|c|c|}
\hline VARIABLES & NO. TESTED & IgG +ve & $x^{2}$ & p-value \\
\hline \multicolumn{5}{|l|}{ Age group } \\
\hline $20-29$ & $52(31.0)$ & $28(53.6)$ & & \\
\hline $30-39$ & $104(61.9)$ & $64(61.5)$ & 13.250 & 0.003 \\
\hline $40-49$ & $12(7.1)$ & $7(58.3)$ & & \\
\hline \multicolumn{5}{|l|}{ Marital Status } \\
\hline Single & $2(1.2)$ & & 10.231 & 0.045 \\
\hline Married & $166(98.8)$ & 99 (59.6) & & \\
\hline \multicolumn{5}{|l|}{ Educational Level } \\
\hline None/primary & $1(0.6)$ & $1(100)$ & & \\
\hline Secondary & $18(10.7)$ & $13(72.2)$ & 8.324 & 0.081 \\
\hline Tertiary & $149(88.7)$ & $85(57.1)$ & & \\
\hline \multicolumn{5}{|l|}{ Occupation } \\
\hline Student & $14(8.3)$ & $6(42.9)$ & & \\
\hline Unemployed & $27(16.1)$ & $18(66.7)$ & & \\
\hline Trading & $55(32.7)$ & $34(61.8)$ & 7.023 & 0.067 \\
\hline Civil Servant & $59(35.1)$ & $31(52.5)$ & & \\
\hline Artisan & $5(3.0)$ & $4(80.0)$ & & \\
\hline Business executive & $8(4.8)$ & $6(75)$ & & \\
\hline \multicolumn{5}{|l|}{ Type of Family } \\
\hline Monogamy & $136(81.0)$ & $77(56.7)$ & 13.546 & 0.005 \\
\hline Polygamy & $32(19.1)$ & $22(68.8)$ & & \\
\hline \multicolumn{5}{|l|}{ Religion } \\
\hline Christian & $154(91.7)$ & $22(68.8)$ & & \\
\hline Islam (Muslim) & $5(3.0)$ & $4(80)$ & 12.786 & 0.046 \\
\hline Free thinkers & $9(5.3)$ & $3(33.3)$ & & \\
\hline \multicolumn{5}{|l|}{ History of Abortion } \\
\hline Yes & $71(42.3)$ & $49(69.0)$ & 8.965 & 0.008 \\
\hline No & $97(57.70)$ & $50(51.6)$ & & \\
\hline \multicolumn{5}{|l|}{ Parity } \\
\hline 0 & $65(38.7)$ & $43(66.2)$ & & \\
\hline $1-2$ & $74(44.1)$ & $37(50)$ & 7.971 & 0.062 \\
\hline $3-4$ & $27(16.1)$ & $17(63.0)$ & & \\
\hline$\geq 5$ & $2(1.2)$ & $2(100)$ & & \\
\hline \multicolumn{5}{|l|}{ Gestation } \\
\hline $1^{\mathrm{st}}$ & $19(11.3)$ & $10(52.6)$ & & \\
\hline $2^{\text {nd }}$ & $74(44.1)$ & $43(58.1)$ & 6.721 & 0.071 \\
\hline $3^{\text {rd }}$ & $75(44.6)$ & $44(58.7)$ & & \\
\hline \multicolumn{5}{|l|}{ STD History } \\
\hline Yes & $20(11.9)$ & $20(100)$ & 15.531 & 0.002 \\
\hline No & $148(88.1)$ & $79(53.4)$ & & \\
\hline
\end{tabular}

Significant at $5 \%$ level of significant

Age: In this study, the highest prevalence of HSV infection was found among the 30 - 39 years age group while the lowest prevalence was observed among the $20-29$ years age group. This may be due to the higher tendency of acquiring the infection as a result of with increasing cumulative years of sexual exposure. However, age was significantly associated with occurrence of HSV-2 antibodies. This is in agreement with report by Kalu et al., 2014. He reported that age is significantly related to $\mathrm{HSV}-\mathrm{IgG}$ infection. This contradicted 
Hayatuden et al., 2017 reported that age was not significantly associated with HSV-2 IgG infection.

Marital Status: In this study, there was high seroprevalence of $59.6 \%$ among the married while noHSV-2 infection was detected among the single. The absence of HSV-2 among the single could be attributed to lack of determinant factors such as contact with infected partner, early age of first sexual activity and other sexually transmitted infections ${ }^{[10]}$. Early exposure to sexual intercourse has been connected to increased risk of sexually transmitted infections (STI) during adolescence ${ }^{[14]}$. The higher prevalence reported in this study may be attributed to active sexual life, multiple sex partners or extramarital affair among married individuals ${ }^{[10]}$. This is contrary to the report by Agabi et al, 2010). Were high prevalence of HSV-2 infection was observed among singles compared to married individuals Agabi et al., 2010: Okonko \& Cookey, 20 15. There was a significant correlation between marital status with HSV-2 prevalence. This agreed with report by Kalu et al, 2014 who reported that there was a significant correlation between marital status and $\lg \mathrm{G}$ prevalence.

Education: This study showed a higher prevalence of HSV-2 infection. It is $100 \%$ for respondents with low educational qualification and $59.6 \%$ for those with high educational qualification. This agrees with the report of Anaebode \& Ajani, 2018 and Hayatuden et al., 2019. 'The seroprevalence of 1-ISV-2 infection was observed to increase with increasing educational qualification similar to report by $\mathrm{Xu}$ et al., 2006 in the United States of America and Aljumaih et al., 2013 in Iraq. Most of the respondents $(88.7 \%)$ with tertiary education may be because the study was tertiary hospital-based and was carried out in an urban centre. Increasing level of education was noticed to be inversely related to HSV-2 infection, this may be explained by the fact that a high level of education is associated with great enlightenment of the infection, its route of transmission and prevention; indicating the positive influence of education and public awareness on the carrier rate of HSV-2 infection. Lack of proper education might give rise to ignorance of acquisition and prevention of $\mathrm{HSV}$ [18]. There is significant correlation between the HSV-2 IgG seropositivitv with level of education of the respondents. This is in agreement with the study
byKalu et al., 2014, Haytudeen et al., 2016 and Agabi et al.,.. 2010. They reported that educational status has no significant effect on the prevalence of HSV-2 $\lg \mathrm{G}$ infection.

Occupation: A lower prevalence of $42.9 \%$ was observed among respondents that were students compared to the unemployed, traders, civil servants, artisans and business executives. This might be explained by the fact that a low level of occupation (student in this study) was an indicator of low socioeconomic status which was a risk factor for HSV-2 infection. This contradicts report by Apurba et al., 2013. According to his study, a high seroprevalence was observed in low socioeconomic group. However, this report agreed with studies performed by Okonko \& Cookey, 2015 and Hayatuden et al., (2017). There was no significant correlation between the prevalence of HSV-2 IgG and occupation of the respondents which is in agreement with Hayatuden et al., 2017 report that occupation is not significantly associated with occurrence of HSV-2 IgG antibodies.

Type of Family: There was a significant association between types of family with prevalence of $\lg \mathrm{G}$. The high prevalence observed among the respondents in a polygamous relationship may be attributed to extramarital relationship by spouse. The lower prevalence in monogamy may be due to earlier marriage associated with short period between premarital sexual debut and marriage associated with low vulnerability.

Religion: Higher HSV-2 seroprevalence was reported among Christians than Muslims. This is in agreement with the study carried out by Aljumaih et al., 2013)which attributed the difference in prevalence of religion to practice of male circumcision at infancy or early childhood by the spouses of the Muslim women and also that Muslim subjects were of low income compared to Christians and other religions. This study showed no significant correlation between religions of respondents with $\mathrm{IgG}$ prevalence. The findings deviated from report by Agabi et al., 2014 where he reported that religion has no significant effect on the prevalence of HSV-2 IgG infection.

History of Abortion: This study shown that there is significant correlation between history of abortion with the prevalence of IgG. But the report of Rothore et al., 2010 revealed that there was no 
significant correlation between history of abortion with the prevalence of IgG.

Parity: The effect of elevated number of previous pregnancies on seropositivity may not be direct but may be a reflection of increasing sexual activity duration which itself is a risk factor for HSV seropositivity. This study showed that the variation in prevalence was statistically not associated with HSV infection. This deviate from the study by Rothore et al., 2010 who reported that parity was significantly related to HSV infection.

Gestation: HSV-2 infection is common among women of reproductive age and it can be contracted and transmitted to the foetus during pregnancy and the newborn. Herpes simplex virus is the major cause of neonatal infection which can lead to death or long- term disabilities. The risk of transmission of the infection to the foetus and the newborn may occurs. The risk of transmission of maternal-fetalneonatal herpes simplex can be reduced by performing a treatment with antiviral medication or resorting to a caesarean section in some specific cases ${ }^{[3]}$. HSV contracted in the course of pregnancy is connected with spontaneous abortion and have its highest occurrence in first trimester ${ }^{[18]}$.

The prevalence of HSV-2 seropositivity gradually rose with increase in trimester period of pregnancy in this study. Most of the respondents were recruited within their second and third trimesters. This is in agreement with similar study performed by Kaluet al., 2014. This study showed no significant correlation between gestation period of the respondents with prevalence of IgG. This is in agreement the study by Okonko \& Cookey, 2015 whose report showed that gestation is not significantly associated with IgG prevalence.

\section{Sexually Transmitted Diseases (STD):}

Herpes simplex virus infection caused by herpes simplex virus type 1 and 2 (HSV-2 and HSV-2) are some of the most common viral sexually transmitted diseases (STD) worldwide [27]. Nevertheless, the role of sexual transmission in the spread of HSV-2 should no longer be overlooked and there is therefore need to educate the general population on the danger of risky sexual behaviour. This study showed a very high prevalence of HSV-2 infection among respondents that had at one point in their life had contracted sexually transmitted disease compared to the respondents that had not contracted sexually transmitted diseases. There is however a significant correlation between HSV-2 IgG seropositivity with history of sexually transmitted diseases. This is in agreement with the report by Ibrahim et al., 2015.

\section{Conclusion}

The results obtained in the study revealed that there is a high prevalence of HSV-2 among pregnant women in Port Harcourt, South South, Nigeria.

Antenatal care provides an excellent opportunity for examining pregnant women for infections which are common and treatable and can be transmitted vertically. HSV-2 infection remain common in pregnant women, therefore, there is need for routine screening of all pregnant women for HSV-2 as well as preempt referral and treatment to reduce perinatal transmission to foetus and neonate.

\section{Acknowledgement}

Special thanks to Dr. Iheanyi Omezuruike Okonkwo of Medical Microbiology Unit, Department of Microbiology, University of Port Harcourt, Nigeria for his laboratory assistance offered during this study.

\section{References}

1 Abu-Raddad LJ, Magaret AS, Celum C, Wald A, Longini IM, Jr., Self SG, Corey L. Genital herpes has played a more important role than any other sexually transmitted infection in driving HIV prevalence in Africa. PLoS One 2008; 3(5): e2230 DOI: 10.1371/journal.pone.0002230

2 Agabi YA, Banwat EB, Mawak JD, Lar PM, Dashe N, Dashen MM, Adoga MP, Agabi FY, Zakari H. Seroprevalence of herpes simplex virus type-2 among patients attending the Sexually Transmitted Infections Clinic in Jos, Nigeria. J Infect Dev Ctries 2010; 4(9): 572575 [PMID: 21045370 DOI: $10.3855 /$ jidc.567

3 Aljumaih, Z.K.M., Alsamarai, A.M. \&Najem, W. Seroprevalence of HSV-2 (HS-2) in women with bad obstetric history. America 
journal of Dermatology and Vene. 2013 Volume 2, no 3, page 31 - 38.

4 Anaedobe CG, Ajani TA. Co-infection of Herpes Simplex Virus Type 2 and HIV Infections among Pregnant Women in Ibadan, Nigeria. J Glob Infect Dis 2019; 11(1): 19-24 DOI: $10.4103 /$ jgid.jgid_56_18

5 Anil, K.B., Uma, K., Yegiang, L., Emese, G., Cellen, A. Vertical transmission of herpes (HSV). Journal of the German Society of Dermatology, 2007 3(5), 29-32

6 Apurba, S.S., Sandhya, B.K., Senthamarai, S., Sivasankari, S., Kumudavathi, M.S., Anitha C. A. \&Amshavathani, S.K. Serological Evaluation of Herpes Simplex Virus Type 1/type 2 Infections in Pregnant women with bad Obstetric History in a tertiary Care Hospital, Kanchipuram. International Journal of Advanced Research,2013 1 (3), 123-128

7 Drisu, U.I., Oronsaye, F.E., Adejumo, B.I.G., Uchuno, G.A., Emmanuel, A.M., Dimkpa, U., Omosor, K.I., Adebowale, M.O., Abdulrahman, O.N. \&Ukatu, E.N. Seroprevalence, type-specific of herpes simplex virus and associated risk factors among women of child bearing age in Kogi State Nigeria. Health, 2018,10, 1006 - 1017 DOI: $10.4236 /$ health.2018.107075

8 Fatahzadeh M, Schwartz RA. Human herpes simplex virus infections: epidemiology, pathogenesis, symptomatology, diagnosis, and management. J Am Acad Dermatol 2007; 57(5): 737-763; quiz 764-736 [PMID: 17939933 DOI: 10.1016/j.jaad.2007.06.027

9 Ghazi HO, Telmesani AM, Mahomed MF. TORCH agents in pregnant Saudi women. Med Princ Pract 2002; 11(4): 180-182 [PMID: 12424411 DOI: $10.1159 / 000065813$

10 Hayatuden,M.R., Mukihtoar. G.I. \&Arninu, M.Seroprevalence of Immunoglobulin $G$ and M Associated with Herpes simplex virus type 2 among apparently healthy individuals in Katsina State, Nigeria,2017 (1), 186-191.

11 Hunt , R. Herpes Viruses.2008 http://pathmicro.med.sc.edu/virol/herpes.htm

12 Ibrahim, A., Adamu, Al. \&Haruna, A. Seroepidemiology of herpes simplex virus type-2(HSV-2) among incarcerated population ofPatiskum Medium Security Prison
PotiskumYobe State: Study of prevalence and associatedrisk factors. 2015 4(3): 632 - 637.

13 Kalu, E. I., Mawak, J.D.\&Dashe, N. Seroprevalene of Herpes simplex virus infection, among pregnant women attending international clinic in Benin, Nigeria.International Journal of Tropical disease and Health, 2014 4(1), 70-81. DOI: 10.9734/IJTDH/2014/6048

14 Kalu EI, Ojide CK, Fowotade A, Nwadike VU. Sexual behavioral correlates with HSV-2 seroprevalence among pregnant women in Nigeria. J Infect Dev Ctries 2014; 8(8): 10061012 DOI: $10.3855 /$ jidc. 4336

15 Moosazadeh, M., Afshari, M., Hamzehgardeshi, Z., Abedi, G., \& Malary, M. The Prevalence of herpes simplex virus type 1 and 2 infection in Iran" A meta-analysis. International Journal of reproaduction Biomed., 2016.14 (10), 615624. DOI: $10.29252 / \mathrm{ijrm} .14 .10 .615$

16 Nakku-Joloba E, Kambugu F, Wasubire J, Kimeze J, Salata R, Albert JM, Rimm A, Whalen C. Sero-prevalence of herpes simplex type 2 virus (HSV-2) and HIV infection in Kampala, Uganda. Afr Health Sci 2014; 14(4): 782-789 DOI: $10.4314 /$ ahs.v14i4.2

17 Ojinmah, U.K., Nnoruka, E.N., Ozoh, G.A., Onyekonwu, C.L. \&Aguwa, E.N. Herpes simplex virus type 2 infection among females in Enugu, Enugu State. Shiraz e Medical Journal, 2012,13(1), 5 - 9.

18 Okonko IO, Cookey TI. Seropositivity and determinants of immunoglobulin-G (IgG) antibodies against Herpes simplex virus (HSV) types -1 and -2 in pregnant women in Port Harcourt, Nigeria. Afr Health Sci 2015; 15(3): 737-747 DOI: 10.4314/ahs.v15i3.6

19 Roizman, B.\&Knipe, D.M.Herpes Simplex Viruses and Their Replication, Chapter 72. In: Fields Virology, Fourth Edition, D.M. Knipe, P.M. Howley et al.,Philadelphia: Lipincott, Williams \& Wilkins, PA.2001 pp. 2399-2459.

20 Rathore S, Jamwal A, Gupta V. Herpes simplex virus type 2: Seroprevalence in antenatal women. Indian J Sex Transm Dis AIDS 2010; 31(1): 11-15 DOI: 10.4103/02537184.68994

21 Sauerbrei A, Schmitt S, Scheper T, Brandstadt A, Saschenbrecker S, Motz M, Soutschek E, 
Wutzler P. Seroprevalence of herpes simplex virus type 1 and type 2 in Thuringia, Germany, 1999 to 2006. Euro Surveill 2011; 16(44) [PMID: 22085620]

22 Sawtell NM, Thompson RL. Comparison of herpes simplex virus reactivation in ganglia in vivo and in explants demonstrates quantitative and qualitative differences. J Virol 2004; 78(14): 7784-7794

DOI: 10.1128/JVI.78.14.7784-7794.2004

23 Straface G, Selmin A, Zanardo V, De Santis M, Ercoli A, Scambia G. Herpes simplex virus infection in pregnancy. Infect Dis Obstet Gynecol 2012; 2012: 385697 DOI: 10.1155/2012/385697

24 Thompson RL, Sawtell NM. Replication of herpes simplex virus type 1 within trigeminal ganglia is required for high frequency but not high viral genome copy number latency. $\boldsymbol{J}$ Virol 2000; 74(2): 965-974 DOI: $\underline{10.1128 / j v i .74 .2 .965-974.2000}$
25 Thompson RL, Sawtell NM. Herpes simplex virus type 1 latency-associated transcript gene promotes neuronal survival. J Virol 2001; 75(14): 6660-6675 DOI: 10.1128/JVI.75.14.6660-6675.2001

26 Whitley, R.J., Kimberlin, D.W. \& Prober, C.G. Herpes Simplex Virus. In: Arvin, A., Campadellifiume, G., Mocarski, E., Moore, P.S., Roizman, B., Whitley, R., Yamanishi, K. Human Herpesviruses: Biology, Therapy and Immunoprophylaxes. New York, Cambridge University Press, 2007,pp. 589 - 601.

$27 \mathrm{Xu} \mathrm{F}$, Sternberg MR, Kottiri BJ, McQuillan GM, Lee FK, Nahmias AJ, Berman SM, Markowitz LE. Trends in herpes simplex virus type 1 and type 2 seroprevalence in the United States. JAMA 2006; 296(8): 964-973 [PMID: 16926356 DOI: $\underline{10.1001 / \text { jama.296.8.964 }}$ 